\title{
SEM STATISTICAL ANALYSES IN MANAGEMENT STRATEGIES
}

\author{
Ren Gui ${ }^{1}$, KaiMan Zeng ${ }^{2}$, NanSong $\mathrm{Wu}^{2}$ and Liang Huang ${ }^{3}$ \\ ${ }^{1}$ San Jose City College, Business and Information Technology Management School, CA, \\ USA \\ ${ }^{2}$ Department of Electrical Engineering, Arkansas Tech University, Russellville, \\ Arkansas, USA \\ ${ }^{3}$ Department of Information \& Electronic Engineering, Zhejiang Gongshang University, \\ HangZhou, ZheJiang, China
}

\begin{abstract}
This paper was to analyse what factors will affect online shoppers' purchase intention in the e-business environment. This paper discussed a number of conceptual models and following hypotheses. Two typical e-business companies (Alibaba and Amazon) were ideal comparative analysis models. Structural Equation Modelling (SEM) and the factor analysis were adopted for statistical and empirical analyses. The results showed highly positive correlations among the identified factors. The factors indicated a large innovative performance influence. The factors also verified the huge impact in the sustain ability development. These results may provide some vision on how e-business companies can win a competition and increase their profit.
\end{abstract}

\section{KEYWORDS}

E-commerce, sustainable innovations, sustainability, management strategies, e-purchase intention, EFA, SEM, path analysis.

\section{INTRODUCTION}

As organizations go online, they have to decide which e-business models best suit their goals. A business model is defined as the organization of products, services and information flows, serving as a source of revenues and benefits for suppliers and customers [1][2]. The concept of an ebusiness model is the same as that of traditional businesses but used in the online context [3][4]. The various types of business models determine marketing strategies [5][6]. For instance, as Alibaba entered into the North American territory, or when Amazon penetrated into the Asian markets, the innovativeness, or the adoption of innovations into their market strategies, varied [7] Wei Cai et al. obtained some numerical results and plotted the optimal energy consumption and efficiency of the medical device, which indicates that the optimal size of those device topology [8].

A marketing strategy is based on customers' behavior expected in a certain market [8][9]. In order to understand the customers and their buying behavior, a process of segmenting and positioning is needed [10][11]. This process consists of the three main activities: segmenting, targeting and positioning. In the present study, the author mainly focuses on two of them: segmenting and positioning [12][13]. Also, factors that influence the consumers' purchase intention are many, e.g., environmental elements, products' life cycle, competitive pressures, patents, R\&D funding and organizational structure [14][15]. While some researchers have focused on either marketing strategies or innovation adoptions, surprisingly little research has DOI : $10.5121 /$ ijdms.2017.9303 
been conducted on the correlations between those two factors and their influence on consumers' purchasing behaviour [16][17][18].

Some researchers have explored the theoretical foundations of value creation in e-business by examining how American and European e-businesses that have recently become publicly-traded corporations create value. Others have found that in e-business new value can be created while transactions are enabled[19][20][21]. Based on the rich data obtained from case studies and informed by theories in entrepreneurship and strategic management, these researchers have developed models on the sources of value creation. Some of these models suggest that the valuecreating potential of e-businesses hinges on four interdependent dimensions: efficiency, complementarities, lock-in, and novelty [22][23][24]. Studies based on these models suggest that no single entrepreneurship or strategic-management theory can fully explain the value-creating potential of an e-business. Rather, an integration of these theoretical perspectives is needed. To facilitate such an integration, some scholars offer the business-model construct as a unit of analysis for future research on value creation in e-business[25][26]. A business model depicts the design of transactional content, structure, and governance so as to create value through the exploitation of business [27][28][29]. Some papers propose that a firm's business model is an important locus of innovation opportunities and a crucial source of value creation for itself and its suppliers, partners, and customers. However, such models have delineated different effects [30][31][32].

Hassan and Stephen (2005) describes segmenting as the process of dividing the market into segments based on customers' characteristics and needs[33][34]. The main segmenting activity consists of four parts: determining who the actual and potential customers are, identifying segments, analyzing the intensity of competitors in the market, and selecting the attractive customer segments [35][36]. It is well known that a company is almost never alone in a market-competitors have a great influence on a business's motivation to enter a certain market [37][38]. When there is a high intensity of competition, it is so hard to obtain a profitable market that a company may decide not to enter a certain market. The third step of segmenting is the first part of a competitor analysis [39]. The need for segmenting a market often arises from the fact that no markets are homogeneous. For a given product, the market can be divided into different customer groups [40].

The variables involved in this kind of segmenting are usually geographical, behavioral and demographic in nature [41][42]. When these segments are known, it is important to determine which market to target. Not every market is an attractive market to enter[43]. A little filtering is usually done in this activity, but there are more factors to take in account before targeting a certain market segment. This process is called targeting[44][45]. After the most attractive segments are selected, a company should not directly start targeting all of them -- other important factors come into play in defining a target market [46][47]. Four sub-activities form the basis for deciding on which segments will actually be targeted[48]. One other critical factor is novel performance in corporation management, which in the present study is defined as in four aspects: financial, marketing, technological and sustainable[49].

E-Commerce Platforms: In this section, the various e-commerce platforms adopted by Alibaba and Amazon will be compared and contrasted [50].

In B2B e-commerce, Alibaba has solved the one problem Amazon can't. In the platform of Alibaba's wholesale market, people everywhere can get access to the Chinese supply chain, through Alibaba.com and 1688.com [51]. This means tinkerers, builders, entrepreneurs and small business operators can order custom motors and parts from Chinese factories without having to travel there, find a scout, and forge a relationship with a manufacturer before doing business [52][53]. It opens up the world of Chinese suppliers to people who wouldn't normally have 
access to it [54]. They can now buy in bulk through Alibaba, which acts as a trusted third party, vouching for the transaction [55].

Alibaba's advantage comes from its proximity to so many of the world's manufacturing assets[56]. Alibaba's wholesale revenue in fiscal 2014 was $\$ 1$ billion, versus $\$ 8$ billion from its retail operations [57]. The company processed a total of \$296 billion's worth of sales on its platform in its last full fiscal year.

E-Commerce Strategies: In this section, different e-commerce strategies adopted by Alibaba and Amazon will be reviewed. Alibaba's business model is not capital intensive. For their last reported financial years, Amazon (December 2014) and Alibaba (March 2015) both generated nearly $\$ 6$ billion cash from operations[58]. Amazon spent more than $\$ 4$ billion of this cash in capital expenditure, which was primarily towards developing additional capacity for its operations. Of this, $\$ 500$ million was spent towards internally used software and website development. Alibaba, on the other hand, spent only $\$ 769$ million on capital expenditure in the fiscal year of 2014 (China Internet Watch, 2014). Since Alibaba's capital expenditure is primarily on its technological platforms, it is much lower than that of Amazon[59].

For the present study, eight different models were selected for an analysis of factors detected from Model 1 to Model 7.

\section{BACKGROUND}

\subsection{Model 1: An Alternative Theoretical Model Of InNOVAtiveness}

In an attempt to understand the role of individual innovativeness in the acceptance of IT-based innovations, Fiedler and Park (2006) illustrate the relationship among innovativeness, innovation characteristics and behavioural intention (see Figure 1)[60].

As shown in Figure 1, under innovativeness there are two independent variables: adopter category innovativeness and personal innovativeness in. Another group of independent variables (usefulness, ease of use, compatibility) are found in the group of innovation characteristics. Both groups have relationship to the depend variable of behavioural intention[61].

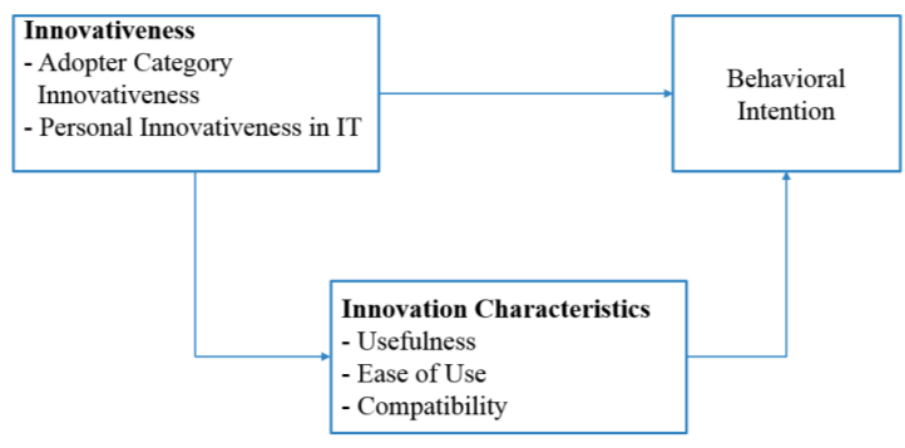

Figure 1. Alternative Theories of Innovativeness

\subsection{Model 2: TECHNOLOGY ACCEPTANCE MODEL}

In a paper on e-commerce adoptions, Lee and Ahn (2004) describe the relationship among external variables, perceived usefulness, perceived ease of use, attitudes toward using and behavioral intention (see Figure 2)[62][63]. 
In Figure 2, there are interrelationships among the independent variables: external variables, perceived usefulness, perceived ease of use to perceived usefulness, perceived usefulness to attitude toward using, perceived ease of use, attitudes toward using, and behavioural intention [64].

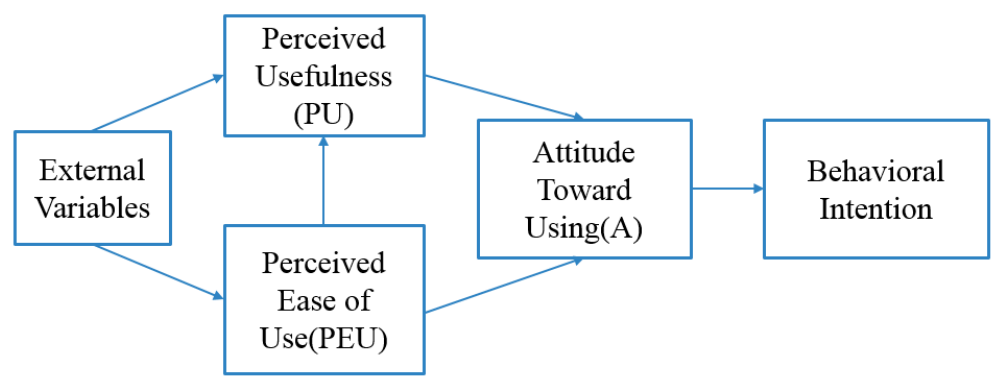

Figure 2. A Model of Technology Acceptance

\subsection{Model 3: New Product Evaluation}

On the topic of purchase intentions and the dimensions of innovation, Holak and Lehmann (2005) depict the complex relationships among communicability, complexity, divisibility, relative advantages, compatibility, perceived risks and purchase intention (see Figure 3)[65].

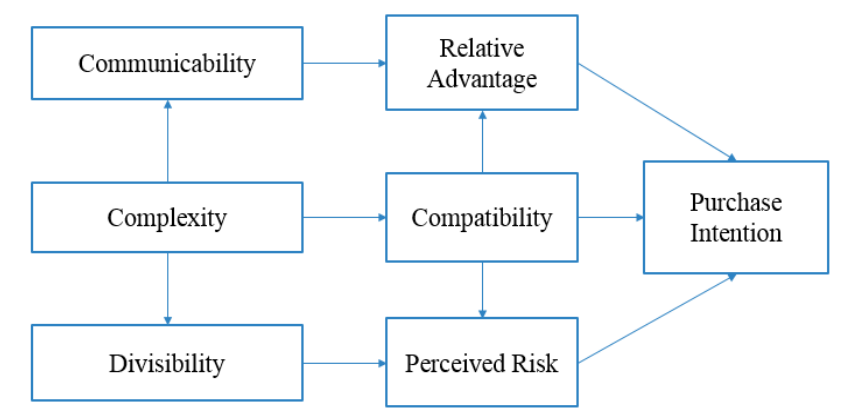

Figure 3. A Model of New Product Evaluation

As shown in Figure 3, model of new product evaluation, there are some relationship between complexity and communicability, complexity and divisibility, communicability and relative advantage, complexity and compatibility, compatibility and relative advantage, compatibility and perceived risk, relative advantage and purchase intention, compatibility and purchase intention, perceived risk and purchase intention[66].

\subsection{Model 4: Extended Relationships Among Price, Information On Product AtTributes And Purchase Intention}

In the paper on the effect of online consumer reviews on consumer purchasing intention. Park et al. (2007) offer a detailed description of the relationships among information on product attributes, objective price, reference price, perceived quality, perceived price, perceived value and purchase intention (see Figure 4)[67]. 


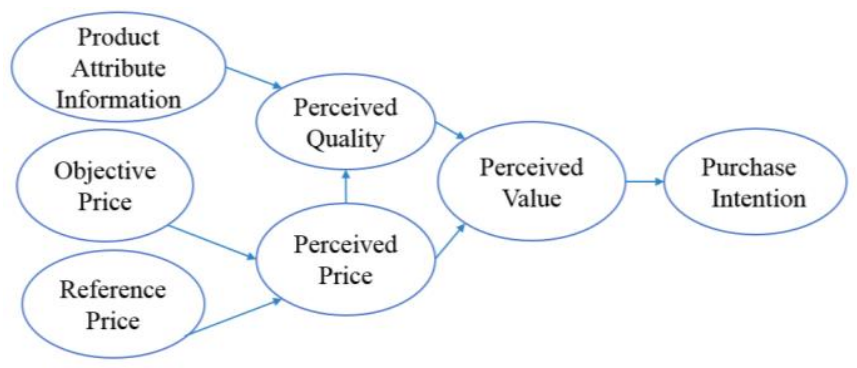

Figure 4. Extended Relationships among Price, Information on Product Attributes and Purchase Intention.

As shown in Figure 4, there are some relationships among information on product attributes, perceived quality, objective price, perceived price, reference price, perceived price, perceived quality, perceived value, perceived price, perceived value, and purchase intention[68].

\subsection{Model 5: Online Purchase Intention}

In a study of user expertise in contemporary information systems, Sedera and Dey (2013) elaborate on the relationships among usability, website design, information quality, trust, perceived risks, empathy, and online purchase intention (see Figure 5). As shown in this figure, all the independent variables (usability, website design, information quality, trust, perceived risks, empathy) have some impact on the dependent variables--online purchase intention[69][70].

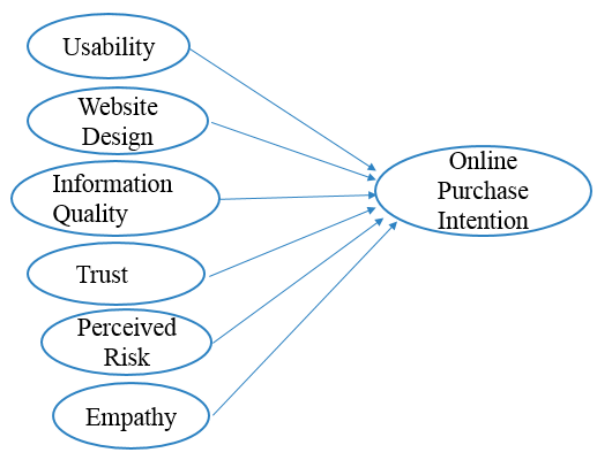

Figure 5. Variables Underlying Online Purchase Intention

\subsection{Model 6: Matrix Of Management Strategies}

Linking global market-segmentation decisions with strategic-position options, Hassan and Stephen (2005) illustrate the relationships among, focused strategies, geo-centric strategies, optimization strategies, localization strategies, and consumers' purchase intention, see Figure 6 as the following[71][72].

As show in Figure 6, there are inter-relationships among independent variables listed under focused strategy, those listed under optimization strategies, those under geo-centric strategies (geo-demographics, micro-demographics, attitude and usage of products ), those under localization strategies, and the dependent variable: consumers' purchase intention[73].

Interestingly, targeting can only be done when segments have been defined, as these segments allow firms to analyze the competitors in the same market [74]. When the process of targeting is ended, the markets to target are selected, but the way to use marketing in these markets is not yet 
defined[75]. To decide on the actual marketing strategies, knowledge of the various advantages of each segment is needed (See Figure 6).

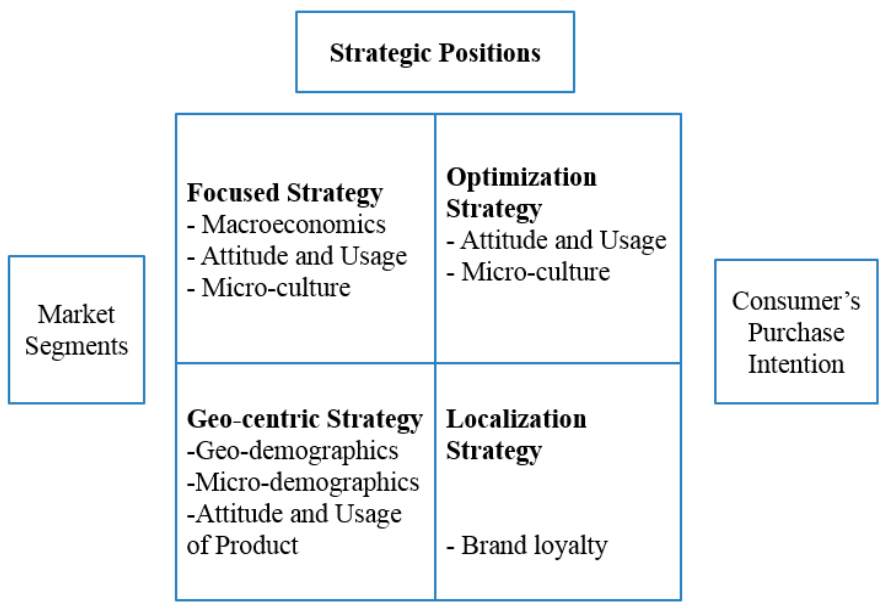

Figure 6. Matrix of Management Strategies for Consumer Marketing

The process-data model shows the concepts underlying the different activities before and during positioning. It shows how the pre-defined concepts are the basis for the positioning statement. The analyses done on the market, competitors and ability of the company are necessary for creating a good positioning statement. Aided with this statement, one can start on creating the marketing $\operatorname{mix}[76]$.

The process described above can be used for both business-to-customer and business-to-business marketing. Although most variables used in segmenting the market are based on customer characteristics, business characteristics can be described with the variables which are not depending on the type of buyers. There are, however, methods for creating a positioning statement for both B2C and B2B segments. One of these methods is MIPS, a method for managing industrial positioning strategies created by Hassan and Stephen[77].

\subsection{Model 7: Effects Of Brands' Credibility And Prestige On Consumers' PURCHASING INTENTION}

Working on the adoption of software measures, Wallace and Sheetz (2014) explored the relationships among brand credibility, brand prestige, perceived risks, perceived value of money and consumer's purchase intention (see Figure 7)[78].

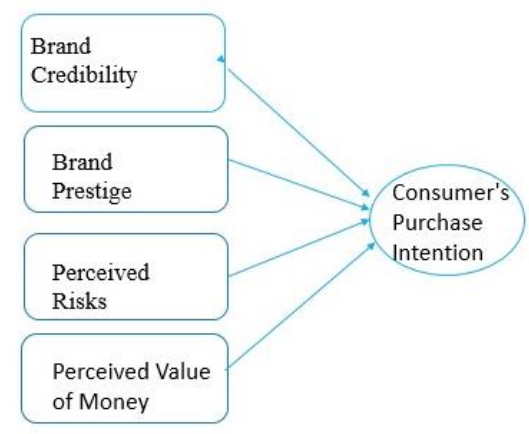

Figure 7. Effects of Brands' Credibility and Prestige on Consumers' Purchasing Intention. 
International Journal of Database Management Systems ( IJDMS ) Vol.9, No.3, June 2017

As shown in Figure 7, independent variables of brand credibility, brand prestige, perceived risks and perceived value of money have effects on the dependent variables of consumers' purchase intention[79].

\subsection{SUMMARY OF VARIABLES}

Based on the foregoing literature review, a list of independent variables and depend variables were identified (see Table 1).

Table 1. Independent and Dependent Variables of the Present Study.

\begin{tabular}{|c|c|c|}
\hline IVs group & IVs details & Reference \\
\hline $\begin{array}{l}\text { G1: Strategic } \\
\text { segmentation and } \\
\text { positioning }\end{array}$ & $\begin{array}{l}\text { IV 1: Macroeconomics } \\
\text { IV 2: Attitude and usage } \\
\text { IV 3: Micro-culture } \\
\text { IV 4:Geo-demographics } \\
\text { IV 5: Brand loyalty }\end{array}$ & Hassan and Stephen (2005) \\
\hline $\begin{array}{l}\text { G2.a: Innovativeness } \\
\text { G2.b: Innovation } \\
\text { characteristics }\end{array}$ & $\begin{array}{l}\text { IV 5: Adopter category } \\
\quad \text { innovativeness } \\
\text { IV 6: Personal innovativeness in IT } \\
\text { IV 7: Usefulness } \\
\text { IV 8: Ease of use } \\
\text { IV 9: Compatibility }\end{array}$ & Fiedler and Park (2006) \\
\hline $\begin{array}{l}\text { G3: Attitude toward } \\
\text { using }\end{array}$ & $\begin{array}{l}\text { IV 10: Perceived usefulness } \\
\text { IV 11: Perceived ease of use } \\
\text { IV 12: External variables }\end{array}$ & Lee and Ahn (2004) \\
\hline G4: Compatibility & $\begin{array}{l}\text { IV 13: Communicability } \\
\text { IV 14: Complexity } \\
\text { IV 15: Divisibility } \\
\text { IV 16: Relative advantages } \\
\text { IV 17: Perceived risks }\end{array}$ & Holak and Lehmann (2005) \\
\hline G5: Perceived value & $\begin{array}{l}\text { IV 18: Information on product } \\
\text { attributes } \\
\text { IV 19: Objective price } \\
\text { IV 20: Reference price } \\
\text { IV 21: Perceived quality } \\
\text { IV 22: Perceived price }\end{array}$ & Park et al. (2007) \\
\hline
\end{tabular}

\subsection{A CONCEPTUAL Model}

Based on the literature reviewed above regarding the groups of independent and dependent variables, it was assumed in the present study that there are also some relationships among the existing models and the models borne out of the qualitative interviews[80]. All the factors detected by these interviews with senior managers, clients, business owners who had had online shopping experience for no less than three years contributed to the dependent variables: e- 
purchase intention[81]. Together, they brought forth a new model, a conceptual model of epurchase intention (see Figure 8).

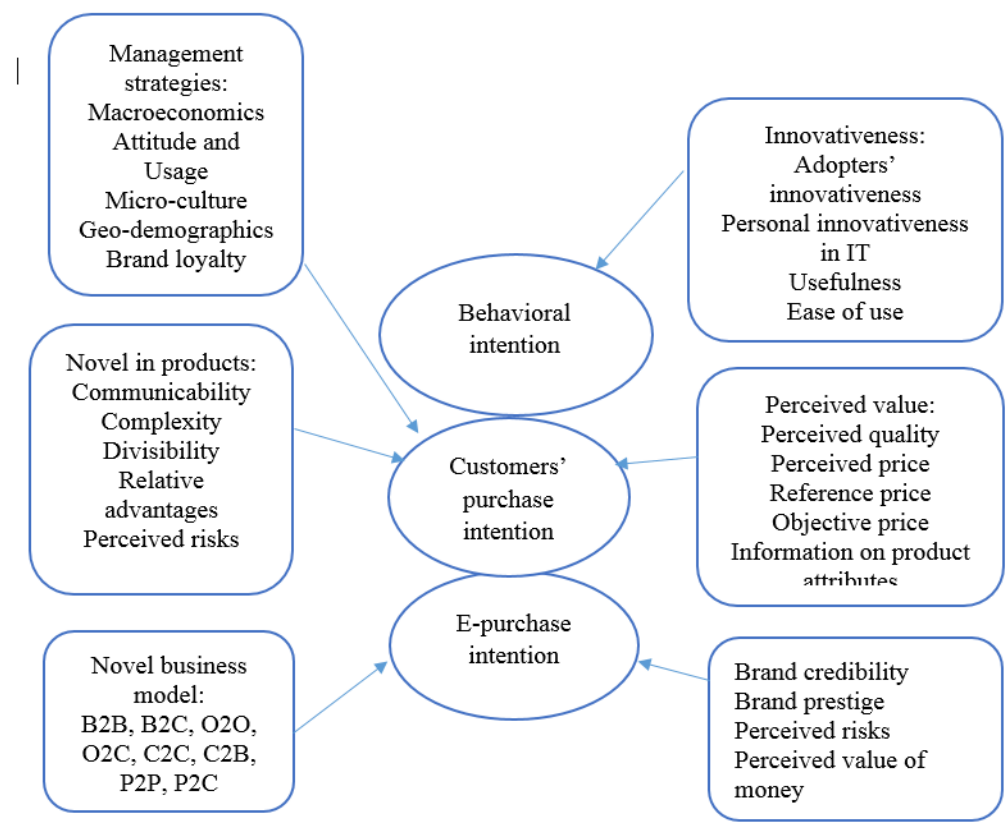

Figure 8. A Conceptual Model of E-Purchase Intention.

\section{METHODS}

\subsection{Model 1: InNOVATION ANd MANAgEMENT STRATEgIES}

In this section, the testing of innovation and management strategies is reported [82]. For Hypothesis 1, the variables involved and the statistical methods used are now described in the following.

H1: There will be a positive relationship between innovation and management strategies.

Observed variables: Ino1 (Innovativeness), Ino 2 (innovativeness), Ino 3 (Ease of use), Ino 4 (Compatibility), Msf 1 (Focus strategies), Msm 2 (Macroeconomics), Msm 3 (Optimization), Msc 4 (Geo-centric strategies).

Latent variables: Innovation and management strategies.

Statistical methods: Structural equations model (SEM).

The following study is prepared in three segments: first one is offending estimates, the second one is constructreliability average and variance extracted, and third one is fit well. Offending estimates: Before evaluating a model's whether it can fit well, offending estimates should be finish it thoughly [83]. An offending estimate means that any parameter value that exceeds its theoretical or acceptable limits. According to Hair et al. [84], two common occurrences in this area are: a negative standard error and a standardized regression weight exceeding or being very close to 1.0. In the present study, the standard error was between.44 and .89 (see Table 2). 
Table 2. Model-1 Regression Weights.

\begin{tabular}{ccllll}
\hline & $\begin{array}{l}\text { Factor } \\
\text { loadings }\end{array}$ & $\begin{array}{l}\text { Squared } \\
\text { multiple } \\
\text { correlations }\end{array}$ & $\begin{array}{l}\text { Error } \\
\text { Variance }\end{array}$ & $\begin{array}{l}\text { Construct } \\
\text { reliability }\end{array}$ & $\begin{array}{l}\text { Average } \\
\text { variance } \\
\text { extracted }\end{array}$ \\
\hline Sus 1 & .682 & .465 & .39 & & \\
Sus 2 & .767 & .588 & .57 & & \\
Sus 3 & .711 & .506 & .44 & & \\
Sus 4 & .720 & .518 & .68 & & \\
& & & & & \\
Msf 1 & .768 & .590 & .89 & .8445 & \\
Msm 2 & .857 & .735 & .56 & & \\
Mso 3 & .781 & .609 & .82 & & \\
Msc 4 & .835 & .697 & .76 & & \\
PR 5 & .564 & .318 & 1.52 & & \\
\hline
\end{tabular}

Note: Estimate $=$ Unstandardized coefficients; $\mathrm{SE}=$ Standard errors; $\mathrm{C} . \mathrm{R} .=$ Critical ratio; $\mathrm{p}=$ Significance: $* \mathrm{p}<.05, * * \mathrm{p}<.01, * * * \mathrm{p}<.001$

The range of standardized regression weights was from .504 to .898 (see Table 3). These results show that there were no offending-estimate issues for Model 1.

Construct reliability and average variance extracted: Claes and Larcker (1981) stated that a model is acceptable when the construct reliability is greater than .7 (See Table 3).

Table 3. Model-1 Variance.

\begin{tabular}{lllll}
\hline & Estimate & S.E. & C.R. & P \\
\hline Ino & .200 & .053 & 3.811 & $* * *$ \\
e11 & 1.196 & .523 & 3.163 & .022 \\
e1 & .898 & .102 & 8.804 & $* * *$ \\
e2 & .566 & .079 & 7.173 & $* * *$ \\
e3 & .811 & .093 & 8.717 & $* * *$ \\
e4 & .760 & .098 & 7.729 & $* * *$ \\
e5 & 1.512 & .149 & 10.180 & $* * *$ \\
& & & & \\
e8 & & & & \\
e9 & .504 & .061 & 8.319 & $* * *$ \\
e10 & .353 & .047 & 7.450 & $* * *$ \\
\hline
\end{tabular}

Note: Estimate $=$ Unstandardized coefficients; $\mathrm{SE}=$ Standard errors; C.R. $=$ Critical ratio; $\mathrm{p}=$ Significance: $* \mathrm{p}<.05, * * \mathrm{p}<.01, * * * \mathrm{p}<.001$

So in the present study the average reliability for perceived risks was calculated at the suggested low limit of .70, with this formula:

$$
\rho_{c 1}=\frac{\left(\sum \lambda_{1}\right)^{2}}{\left[\left(\sum \lambda_{1}\right)^{2}+\sum \theta_{1}\right]}
$$

The construct reliability of relative benefits in Model 1 was calculated by the following formula and the numbers shown in Table 4. 


$$
\rho_{v 1}=\frac{\left(\sum \lambda_{1}^{2}\right)}{\left[\left(\sum \lambda_{1}^{2}\right)+\sum \boldsymbol{\theta}_{1}\right]}
$$

Table 4. Model-1 Standard Regression Weights.

\begin{tabular}{llll}
\hline & & & Estimate \\
\hline Ino 1 & $<-$ & Msf 1 & .314 \\
Ino 2 & $<-$ & Msm 2 & .517 \\
Ino 3 & $<-$ & Mso 3 & .583 \\
Ino 4 & $<-$ & Msf 4 & .693 \\
Ino 2 & $<-$ & Msf 1 & .745 \\
Ino 3 & $<-$ & Msm 2 & .717 \\
Ino 4 & $<-$ & Mso 3 & .781 \\
Ino 3 & $<-$ & Msf 1 & .856 \\
Ino 4 & $<-$ & Msm 2 & .783 \\
Ino 1 & $<-$ & Msm 2 & .836 \\
Ino 1 & $<-$ & Mso 3 & .564 \\
\hline
\end{tabular}

Note: Estimate $=$ Standardized coefficients

The higher the average variance is extracted, the better the observed variables are in explaining the latent variable.

The average variance extracted from perceived risks was calculated at a suggested low limit of .50 , with the following formula and the numbers shown in Table 5 :

$$
\rho_{c 2}=\frac{\left(\sum \lambda_{2}\right)^{2}}{\left.\left(\sum \lambda_{2}\right)^{2}+\sum \theta_{2}\right]}
$$

The average variance extracted from relative benefits in Model 1 was calculated at the suggested low limit of .50 and according to Table 5 as well as this formula:

$$
\rho_{v 2}=\frac{\left(\sum \lambda_{2}^{2}\right)}{\left.\left(\sum \lambda_{2}^{2}\right)+\sum \theta_{2}\right]}
$$


International Journal of Database Management Systems ( IJDMS ) Vol.9, No.3, June 2017

Table 5. Model-1 Factor Loadings, Construct Reliability and AVE.

\begin{tabular}{llllll}
\hline & $\begin{array}{l}\text { Factor } \\
\text { loadings }\end{array}$ & $\begin{array}{l}\text { Squared } \\
\text { multiple } \\
\text { correlations }\end{array}$ & $\begin{array}{l}\text { Error } \\
\text { Variance }\end{array}$ & $\begin{array}{l}\text { Construct } \\
\text { reliability }\end{array}$ & $\begin{array}{l}\text { Average } \\
\text { variance } \\
\text { extracted }\end{array}$ \\
\hline Ino 1 & .781 & .587 & .90 & & \\
Ino 2 & .856 & .733 & .57 & & \\
Ino 3 & .783 & .613 & .81 & & \\
Ino 4 & .836 & .698 & .76 & & \\
& & & & .7623 & \\
& & & & & \\
Msf 1 & .717 & .515 & .41 & & \\
Msm2 & .745 & .554 & .35 & & \\
Mso 3 & .693 & .480 & .50 & & \\
Msc 4 & .583 & .340 & .66 & & \\
& & & & & \\
& & & & & \\
\end{tabular}

$\rho \vee 2$ is the average variance extracted from relative benefits in Model 1.

In summary, the construct reliability and average variance in Model 1 were satisfactory, both being higher than the suggested values $(.70, .50$, respectively)[85]. This means that the inner quality of Model 1 was acceptable for further analyses (see Table 6).

Goodness of fit: Figure 9 is a graphic representation of Model 1. For this model, chi square was $55.754($ degree of freedom $=33, \mathrm{CMIN} / \mathrm{DF}=1.690$, probability level $=.008)$.

All the critical values fit into the recommended index value, with $\mathrm{p}=.008$. GFI (.955), IFI (.975), TLI (.966) and CFI (.975) are greater than .9. NFI (.941) and AGFI (.924) are greater

Table 6. Model-1 Regression Weights.

\begin{tabular}{llll}
\hline & & & Estimate \\
\hline Ino 1 & $<$ & Msf 1 & .314 \\
Ino 2 & $<$ & Msm 2 & .517 \\
Ino 3 & $\leftarrow-$ & Mso 3 & .583 \\
Ino 4 & $\leftarrow-$ & Msf 4 & .693 \\
Ino 2 & $\leftarrow-$ & Msf 1 & .745 \\
Ino 3 & $\leftarrow-$ & Msm 2 & .717 \\
Ino 4 & $\leftarrow-$ & Mso 3 & .781 \\
Ino 3 & $\leftarrow-$ & Msf 1 & .856 \\
Ino 4 & $<-$ & Msm 2 & .783 \\
Ino 1 & $<-$ & Msm 2 & .836 \\
Ino 1 & $<-$ & Mso 3 & .564 \\
\hline
\end{tabular}

Note: Estimate $=$ Unstandardized coefficients; $\mathrm{SE}=$ Standard error; C.R. $=$ Critical ratio; $\mathrm{p}=$ Significance: $* \mathrm{p}<.05, * * \mathrm{p}<.01, * * * \mathrm{p}<.001$ than .8 , RMSEA (.055) lower than .1, PCFI (.715) and PNFI (.690) greater than .5. These indexes suggest that Model 1 had a good model fit. 


\subsection{DisCUSSION FOR MODEL 1}

In the present study, SEM was employed to analyze the details of Model 1. In the following paragraphs, certain variables are explained due to their high correlation coefficients in Figure 9.

In Figure 9, the standardized regression weight is -.81 between relative benefits and perceived risks. The standardized regression weight is significantly high between these two factors. These results suggest that relative benefits significantly influenced perceived risks. The detailed standardized regression weights about relative benefits and perceived risks will be displayed in the following paragraph.

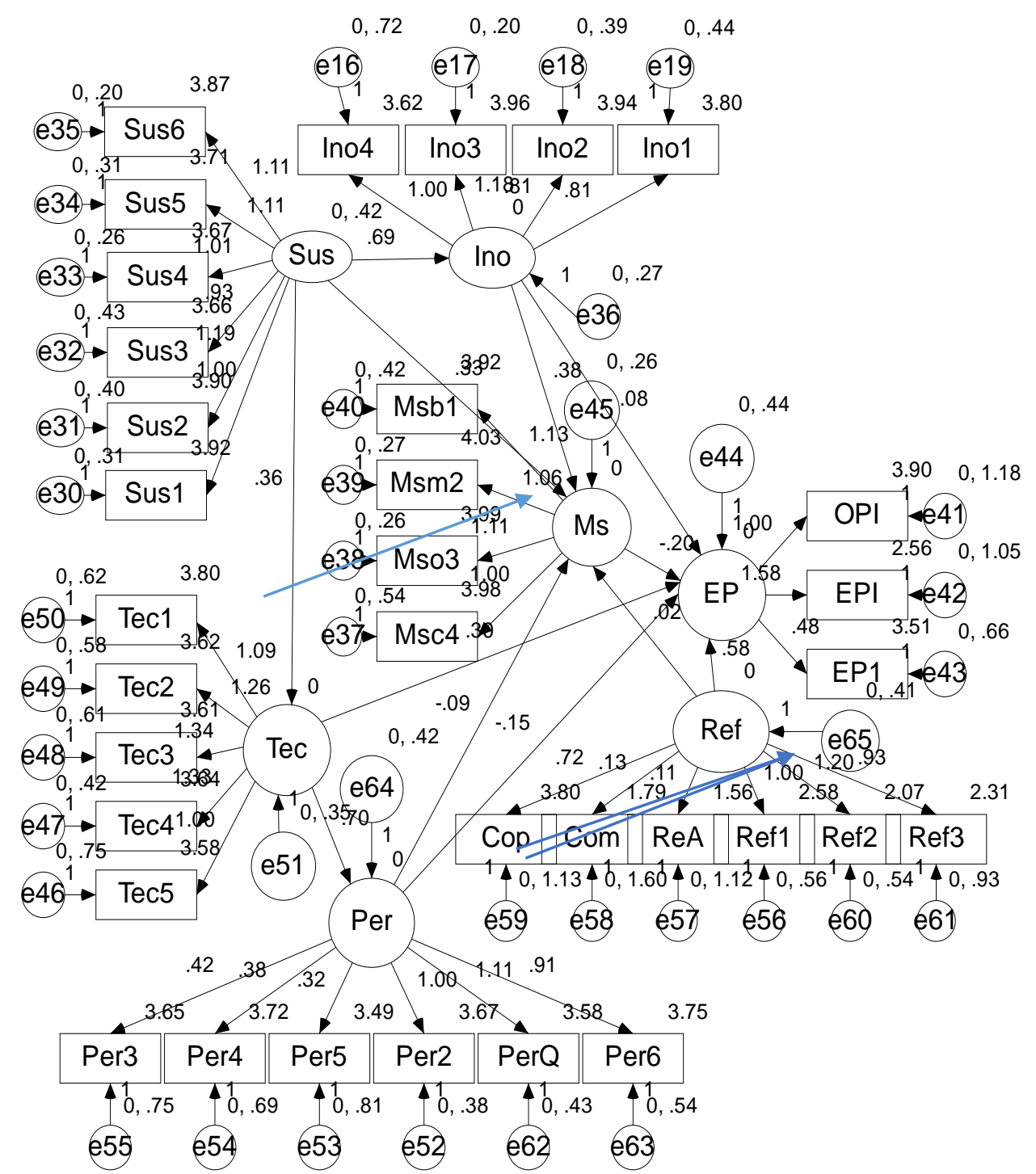

Figure 9. Model-1 Path Diagram.

Ino 1 (Innovativeness), Ino 2 (Personal innovativeness), Ino 3 (Ease of use), Ino 4 (Compatibility), Msf1 (Focus strategies), Msm 2 (Macroeconomics), Msm 3 (Optimization), Msc4 (Geo-centric strategies) were interrelated, and personal innovativeness in IT was the most influential variable for focus management strategies[86]. 


\subsection{Model 2: Technological EfFiciency And Perceived Value}

This section presents the testing of the causal relationship between relative benefits and behavioral intention in using mobile banking[87][88]. For Hypothesis 2, the variables involved and the statistical methods used are described in the following[89]:

All of the standardized regression weights are below 1.0[90]. Thus, it is clear that the offending estimates did not occur in Model 2[91][92]. Clearly, then, the results on offending estimates are acceptable for Model 2[93][94]. Construct reliability and average variance extracted: Claes and Larcker [95], indicated that a model is acceptable when the construct reliability is greater than .7 and that the Average Variance Extracted (AVE) needs to be larger than .5 to be acceptable[96].

Table 7. Model-2 Variances.

\begin{tabular}{lllll}
\hline & Estimate & S.E. & C.R. & P \\
\hline Per & .216 & .054 & 4.037 & $* * *$ \\
e12 & .380 & .071 & 5.337 & $* * *$ \\
e1 & .642 & .071 & 9.058 & $* * *$ \\
e2 & .860 & .097 & 8.893 & $* * *$ \\
e3 & .669 & .073 & 9.188 & $* * *$ \\
e4 & .446 & .048 & 9.317 & $* * *$ \\
e5 & .597 & .067 & 8.903 & $* * *$ \\
e6 & .359 & .039 & 9.316 & $* * *$ \\
e7 & .532 & .054 & 9.849 & $* * *$ \\
e8 & .627 & .067 & 9.415 & $* * *$ \\
e9 & .484 & .057 & 8.459 & $* * *$ \\
e10 & .377 & .046 & 8.237 & $* * *$ \\
e11 & .449 & .052 & 8.704 & $* * *$ \\
\hline
\end{tabular}

Note: Estimate $=$ Unstandardized coefficients; $\mathrm{SE}=$ Standard errors; $\mathrm{C} . \mathrm{R} .=$ Critical ratio $; \mathrm{p}=$ Significance: $* \mathrm{p}<.05, * * \mathrm{p}<.01, * * * \mathrm{p}<.001$

In the present study, the construct reliability for behavioral intention was calculated at the suggested low limit of .70 [97], with this formula (See Table 8)[98]:

$$
\rho_{c 1}=\frac{\left(\sum \lambda_{1}\right)^{2}}{\left[\left(\sum \lambda_{1}\right)^{2}+\sum \theta_{1}\right]}
$$


International Journal of Database Management Systems ( IJDMS ) Vol.9, No.3, June 2017

Table 8. Model-2 Standardized Regression Weights.

\begin{tabular}{|c|c|c|c|}
\hline & & & Estimate \\
\hline Tech 1 & $<-$ & Per 1 & .711 \\
\hline Tech 2 & $<-$ & Per 2 & .537 \\
\hline Tech 3 & $<$ & Per 3 & .610 \\
\hline Tech 4 & $<$ & Per 4 & .708 \\
\hline Tech 1 & $<$ & Per 5 & .724 \\
\hline Tech 2 & $<$ & Per 6 & .688 \\
\hline Tech 3 & $<$ & Per 1 & .738 \\
\hline Tech3 & $<$ & Per 2 & 753 \\
\hline Tech 4 & $<$ & Per 3 & .725 \\
\hline Tech 1 & $<$ & Per 4 & .710 \\
\hline Tech 2 & $<$ & Per 5 & .752 \\
\hline Tech 3 & $<-$ & Per 6 & .710 \\
\hline
\end{tabular}

Note: Estimate $=$ Standardized coefficients

\subsection{DisCUSS FOR MODEL 2}

The construct reliability for relative benefits in Model 2 was calculated at the suggested low limit of .70 [99], according to Table 9 and the following formula

Table 9. Model-2 Factor Loadings, Construct Reliability and AVE.

\begin{tabular}{ccclll}
\hline & Factor loadings & $\begin{array}{l}\text { Squared } \\
\text { multiple } \\
\text { correlations }\end{array}$ & $\begin{array}{l}\text { Eror } \\
\text { variance }\end{array}$ & $\begin{array}{l}\text { Construct } \\
\text { reliability }\end{array}$ & $\begin{array}{l}\text { Average } \\
\text { variance } \\
\text { extracted }\end{array}$ \\
\hline Per 1 & .738 & .545 & .64 & \\
Per 2 & .753 & .567 & .86 & & \\
Per 3 & .725 & .525 & .67 & \\
Per 4 & .710 & .504 & .45 & \\
Per 5 & .752 & .566 & .60 & \\
Per 6 & .710 & .504 & .36 & .4728 \\
& & & & \\
Tec 1 & .688 & .474 & .45 & \\
Tec 2 & .724 & .524 & .38 & \\
Tec 3 & .708 & .501 & .48 & \\
Tec 4 & .610 & .373 & .63 & \\
\end{tabular}

$.8121 \quad .4664$

$\rho c 2$ is the construct reliability for relative benefits in Model 2. Let $\lambda 2$ be the standardized loadings for relative benefits [100]. Let $\theta 2$ be the error variance for relative benefits. Based on the data in Table 4-21, the construct reliability for relative benefits is shown in Model 2[101]. 
The average variance extracted from behavioral intention was calculated at the suggested low limit of .50, with this formula [102][103]:

$$
\rho_{v 1}=\frac{\left(\sum \lambda_{1}^{2}\right)}{\left[\left(\sum \lambda_{1}^{2}\right)+\sum \theta_{1}\right]}
$$

$\rho v 1$ is the average variance extracted of behavioral intention [104]. Based on the data in Table 9, the average variance extracted of behavioral intention is 482 [105].

The average variance extracted from relative benefits in Model 2 was calculated at the suggested low limit of .50, with this formula [106]:

$$
\rho_{v 2}=\frac{\left(\sum \lambda_{2}^{2}\right)}{\left[\left(\sum \lambda_{2}^{2}\right)+\sum \theta_{2}\right]}
$$

$\rho v 2$ is the average variance extracted from relative benefits in Model 2[107]. Based on the data in Table 9, the average variance extracted from relative benefits in Model 3 is .4771 [108].

Goodness of fit: For this model, chi square is 105.071 (degree of freedom $=43, \mathrm{CMIN} / \mathrm{DF}=$ 2.444 , probability level $=.000)$ [109]. All the critical values fit into the recommended index value with $\mathrm{p}=.000$. GFI (.920), IFI (.941), TLI (.923) and CFI (.940) were greater than .9; NFI (.904) and AGFI (.877) were greater than .8. These indices clearly show that Model 2 had a good model fit [110][111].

In summary, the construct reliability and average variance extracted in Model 2 were considered satisfactory as both were much higher than the suggested values (.70 and .50, respectively) [112]. This suggests that the inner quality of Model 2 was acceptable and deserving further analyses (See Table 10) [113].

\begin{tabular}{|c|c|c|c|c|c|}
\hline & Factor loadings & $\begin{array}{l}\text { Squared } \\
\text { multiple } \\
\text { correlations }\end{array}$ & $\begin{array}{l}\text { Error } \\
\text { Variance }\end{array}$ & $\begin{array}{l}\text { Construct } \\
\text { reliability }\end{array}$ & $\begin{array}{l}\text { Average } \\
\text { variance } \\
\text { extractec }\end{array}$ \\
\hline Per 1 & .738 & .545 & .64 & & \\
\hline Per 2 & .753 & .567 & .86 & & \\
\hline Per 3 & .725 & .525 & .67 & & \\
\hline Per 4 & .710 & .504 & .45 & & \\
\hline Per 5 & .752 & .566 & .60 & & \\
\hline \multirow[t]{2}{*}{ Per 6} & .710 & .504 & .36 & & \\
\hline & & & & .8432 & .4728 \\
\hline Tec 1 & .688 & .474 & .45 & & \\
\hline Tec 2 & .724 & .524 & .38 & & \\
\hline Tec 3 & .708 & .501 & .48 & & \\
\hline Tec 4 & .610 & .373 & .63 & & \\
\hline & & & & .8121 & .4664 \\
\hline
\end{tabular}

Table 10. Model-2 Regression Weights. 
Note: Estimate $=$ Unstandardized coefficients, $\mathrm{SE}=$ Standard errors, C.R. $=$ Critical ratio, $\mathrm{p}=$ Significance: $* \mathrm{p}<.05, * * \mathrm{p}<.01, * * * \mathrm{p}<.001$

\section{Conclusions}

Results focused on data analyses are systematically presented [114]. An empirical factor analysis was expended to investigate the sustainable innovation effects in e-purchase management strategies [115][116]. Consequently, SEM was utilized to build a model for sorting out the individual models interrelationships [117][118]. All the above hypotheses tested with SEM, some results had numerical significance and, therefore, were accepted [119][120].

\section{REFERENCES}

[1] Adams, D. A., Nelson, R. R., and Todd, P. A, (1992) "Perceived usefulness, ease of use, and usage of information technology: A replication", MIS Quarterly, Vol. 16, No. 2, pp. 227-247.

[2] Agarwal, R., and Prasad, J, (1997) "The role of innovation characteristics, and perceived voluntariness in the acceptance of information technologies", Decision Sciences, Vol. 28, No. 3, pp. 557-582.

[3] Amit, R., Zott, C., "Value creation in E-business", Strategy Management Journal, Vol. 22, pp. 493520, 2001.

[4] Anckar, B., and D'lncau, D, (2002) "Value creation in mobile commerce: Findings from a consumer survey", Journal of Information Technology Theory and Application, Vol. 4, pp. 43-64.

[5] Amor, D, (1999) “The e-business (r) evolution”, Upper Saddle River, OH, Prentice Hall,.

[6] Anderson, E., and Weitz, B, (1989) "Determinants of continuity in conventional industrial channel dyads", Marketing Science, Vol. 8, pp. 310-314.

[7] W. Cai, J. Gong and N. Wu, (2016) "2.4GHZ Class F Power Amplifier for Wireless Medical Sensor Network", Proceedings of the 2 nd World Congress on New Technologies (NewTech'16) : Fundamentals and Applications.

[8] W. Cai, L. Huang and N. Wu, (2016) "Low Power Class E Power Amplifier for Wireless Medical Sensor Network", Int. J. of Enhanced Research in Sci., Tech. \& Eng., Vol. 5, Iss. 4, pp 145-150.

[9] Arbuckle, J. L., and Wothke, W, (1995) "AMOS 4.0 user's guide", Chicago: Small Waters Corporation.

[10] Burgess, S., Sellitto, C., and Karanasios, S, (2009) "Effective web presence solutions for small businesses: Strategies and successful implementation”, IGI Global Economy, Vol. 9, pp. 210-212.

[11] Bergeron, F., Rivard, S., and De Serre, L, (1990) "Investigating the support role of the information center". MIS Quarterly, Vol. 14, No. 3, pp. 247-259.

[12] Bharati, P., and Chaudhury, A, (2004) "An empirical investigation of decision-making satisfaction in web-based decision support systems", Decision Support System, Vol. 37,pp. 187-197.

[13] Bobbitt, L.M., and Dabholkar, P. A, (2001) "Integrating attitudinal theories to understand and predict use of technology-based self-service: The Internet as an illustration", International Journal of Service Industry Management, Vol. 12, No. 5,pp. 423-450.

[14] Bollen, K. A, (1986) "Sample size and Bentler and Bonett's Nonnormed Fit Index", Psychometrika, Vol. 51, pp. 375-377.

[15] Brandt, Richard L, (2011)“One Click: Jeff Bezos and the Rise of Amazon.com”, New York: Portfolio Penguin.

[16] Brace, N., Kemp, R., and Snelgar, R, (2006) "SPSS for psychologists: A guide to data analysis using SPSS for windows", 2nd ed, Mathwah, New Jersey: Lawrence Erlbaum.

[17] Byrne, B. N, (2001) "Structural equation modeling with AMOS: Basic concepts, applications and programming", Mahwah, NJ: Lawrence Erlbaum Associates.

[18] Chen J.C., Brandy W. Mariam, Wong L, (2013)“Success of electronic commerce Web sites: A comparative study in two Countries", Information and Management 50, pp. 344-355.

[19] China Internet Watch, (2014)“A Glimpse at Chinese Internet Giants”, 2013 Financial Statements Read more: http://www.chinainternetwatch.com/7276/a-glimpse-at-chinese-internet-giants-2013financial-statements/, Viewed Available on May 28. 
[20] Chae, M., and Kim, J, (2004) "Do size and structure matter to mobile users? An empirical study of the effects of screen size, information structure, and task complexity on users activities with standard web phones", Behavior and Information Technology, Vol. 23, No. 3, pp.165-181.

[21] W. Cai, B. Wu and N. Wu, (2016) "2.4 GHz Class F Power Amplifier for Healthcare Application", Int. J. of Computer Sci. and Information Tech., Vol. 7, No. 3, pp. 1086-1090.

[22] W. Cai, C. Li and H. Gu, (2016) "Low Power SI Based Power Amplifier For Healthcare Application" ,Int. J. of Ph1 armacy and Pharmaceutical Sci., Vol 8, Iss. 9, pp171-178.

[23] W. Cai, Liang Huang and S. Wang, (2016) "Class D Power Amplifier For Medical Application", Informatics Eng., an Int. J., Vol.4, No.2, pp9-15.

[24] Chin, W. C., and Todd, P. A, (1995) "On the use, usefulness and ease of use of structural equation modeling in MIS research: A note of caution”, MIS Quarterly, Vol. 19, No. 2, pp. 237-246.

[25] Claes, F., and Larcker, D. F, (1981) "Evaluation structural equation models with unobservable variables and measurement errors", Journal of Marketing Research, Vol. 18, No. 1, pp. 39-50.

[26] Cohen, J., Cohen, P., West, S. G., and Aiken, L. S, (2003) "Applied multiple regression/correlation analysis for the behavioral sciences" (3rd ed.). Mahwah, NJ: Lawrence Earlbaum Associates,.

[27] Davis, L. D., Bagoozzi, R. P., and Warshaw, P. R, (1989) "User acceptance of computer technology: A comparison of two theoretical models", Management Science, Vol. 35, No. 8, pp. 982-1003.

[28] Davies, B. P, (2004) “E-Business”, Palgrave, Basingstoke, pp. 380-395.

[29] Dickey, M, (2013) "The new CEO of China's most important e-commerce company is ready to go public", Business Insider, Vol. 23, No. 2, pp. 56-58.

[30] Devaraj, S., Fan, M., and Kohli, R, (2002) "Antecedents of B2C channel satisfaction and preference: Validating e-commerce metrics", Information Systems Research, Vol. 13, No. 3, pp. 316-334.

[31] Donny, K., and Denny, T, (2014) “Alibaba buys China Vision stake for $\$ 804$ million; gains TV, movie content", Reuters.

[32] Epstein, J., and Gady, W, (2011) “Alibaba's Jack Ma fights to win back trust”, Forbes, Retrieved, September 23, 2012, from http://www.forbes.com/forbes/2011/0411/.

[33] Everard, A., and Galletta, D, (2006) “ How presentation flaws affect perceived site quality, trust, and intention to purchase from an online store", Journal of Management Information System, Vol. 22, No. 3, pp. 55-95.

[34] Featherman, M. S., and Pavlou, P. A, (2003) "Predicting e-services adoption: A perceived risk facets perspective", International Journal of Human-Computer Studies, Vol. 59, pp. 451-474.

[35] W. Cai, L. Huang and W. Wen, (2016) “Low Power Class AB SI Power Amplifier For Wireless Medical Sensor Network", Bioscience \& Eng.: An Int. J., Vol.3, No.3.

[36] W. Cai and F. Shi, (2016) "High Performance SOI RF Switch for Healthcare Application", Int. J. of Enhanced Research in Sci., Tech. \& Eng., Vol. 5, Iss. 10, pp23-28.

[37] W. Cai, J. Xu and S. Wang, (2016) "Low Power SI Class E Power Amplifier for Healthcare Application", International Journal of Electronics Communication and Computer Eng., Vol. 7, Iss. 6, pp 290-293.

[38] Fillis, I. S., Sandy, W., and Park, J. "Factors impacting on e-business adoption and development in the smaller firm", International Journal of Entrepreneurial Behaviour and Research, Vol. 10, pp. 178191, 2004.

[39] Fiedler, J. L., and Park, T. W, (2006) "Understanding the role of individual innovativeness in the acceptance of IT-based innovations: Comparative analyses of models and measures", Decision Sciences, Vol. 37, No. 3, pp. 393-426.

[40] Fredriksson, T, (2013) "Workshop on e-commerce, development and SMEs: Conference on Trade and Development", E-Marketer, Vol. 7, No. 24.

[41] Fung, R., and Lee, M, (1999) "EC-trust: Exploring the antecedent factors", America's Conference on Information Systems, Vol. 179, No. 56.

[42] Goodhue, D. L., and Thompson, R. L, (1995) “Task-technology fit and individual performance”, MIS Quarterly, Vol. 19, No. 2, pp. 213-236.

[43] W. Cai, J. Xu, and L. Huang, (2016) "Low Power SI Class E Power Amplifier And RF Switch for HealthCare", Informatics Engineering, an International Journal, Vol.4, No.4, pp 7-13.

[44] W. Cai, C. Li and S. Luan, (2016) "SOI RF Switch for Wireless Medical Sensor Network", Advances in Eng.: an Int. J., Vol. 1, No.2, , pp 1-9.

[45] Hair, J. F., Anderson, R. E., Tatham, R. L., and Black, W. C, (1998) "Multivariate data analysis with readings", 5th ed, Englewood Cliffs, NJ: Prentice-Hall International.

[46] Hassan and Stephen, (2005) "Linking global market segmentation decisions with strategic positioning options", The Journal of Consumer Marketing, Vol. 22, No. 2/3, pp. 81-89. 
International Journal of Database Management Systems ( IJDMS ) Vol.9, No.3, June 2017

[47] Ho, R, (2006) "Structural equation modeling: Handbook of univariate and multivariate data analysis and interpretation with SPSS", Boca Ration, FL: Chapman and Hall/CR.

[48] Holak, S. L., and Lehmann, D. R, (2005) "Purchase intentions and the dimensions of innovation: An exploratory model", Journal of Product Innovation Management, Vol. 7, No. 1, pp. 59-73.

[49] Jung, T, (2004) “Analysis of moment structures”, Taipei: Wunan Book Co., Ltd.

[50] Kaiser, H. F, (1974) “An index of factorial simplicity”, Psychological Measurement, Vol. 39, No. 1, pp. 31-35.

[51] Kim, D., and Benbasat, I, (2003) "Trust-related arguments in Internet stores: A framework for evaluation", Journal of Electronic Commerce Research, Vol. 4, No. 2, pp. 49-64.

[52] W. Cai and L. L. Gouveia, (2013) "Modelling and simulation of Maximum power point tracker in Ptolemy", J. of Clean Energy Technologies, Vol. 1, No. 1, PP 6-9.

[53] W. Cai, J. Chan and D. Garmire, (2011) "3-Axes MEMS Hall-Effect Sensor", 2011 IEEE Sensors Applications Symposium, pp141-144.

[54] W. Cai, X. Cui and X. Zhou, (2011) "Optimization of a GPU Implementation of Multi-dimensional RF Pulse Design Algorithm," Int. Con. on Bioinformatics and Biomedical Engineering.

[55] Lederer, A. L., Maupin, D. J., Sena, M. P., and Zhuang, Y, (2000) “The technology acceptance model and the World Wide Web", Decision Support Systems, Vol. 29, No. 3, pp. 269-282.

[56] Luarn, P., and Lin, H. H, (2005)“"Toward an understanding of the behavioral intention to use mobile banking", Computers in Human Behavior, Vol. 21, No. 6, pp. 873-891.

[57] Lu, J., Yu, C. S., Liu, C., and Yao, J. E, ( 2003) "Technology acceptance model for wireless internet", Internet Research, Vol. 13, No. 3, pp. 206-222.

[58] W. Cai, L. Huang and W. Wen, (2016) "2.4GHZ Class AB Power Amplifier for Healthcare Application", Int. J. of Biomed. Eng. and Sci., Vol. 3, No. 2.

[59] Wei Cai and Frank Shi, "DESIGN OF LOW POWER MEDICAL DEVICE", Int J of VLSI design \& Comm Sys (VLSICS, Vol.8, No.2, pp1-7, 04/2017.

[60] Wei Cai and Frank Shi, "Design of Low Power Si Based DPA for Medical Device", Int J of Ele Comm and Computer Eng, Vol. 8, Iss. 2, pp134-136, 2017.

[61] McKnight, D. H., Choudhury, V., and Kacmar, (2002) "Developing and validating trust measures for e-Commerce: An integrative typology", Information Systems Research, Vol. 13, pp. 297-32.

[62] Min, Q., Ji, S., and Qu, G, (2008) "Mobile commerce user acceptance study in China: A revised UTAUT model", Tsinghua Science and Technology, Vol. 13, No. 3, pp. 257-264.

[63] Moore, G. C., and Benbasat, I, (1991) "Development of an instrument to measure the perceptions of adopting an information technology innovation", Information Systems Research, Vol. 2, No. 3, pp. 192-222.

[64] Oppenheim, A, (1994) "Questionnaire design, interviewing and attitude measurement", Journal of Community and Applied Social Psychology, Vol. 5, No. 4, pp.371-372.

[65] Park, J., Lee, D., and Ahn, J, (2004) "Risk-focused e-commerce adoption model: A cross country study”, Journal of Global Information Technology Management, Vol. 7, No. 2, pp. 6-30.

[66] Park, J., Yang, S., and Lehto, X, (2007) "Adoption of mobile technologies for Chinese consumers", Journal of Electronic Commerce Research, Vol. 8, No. 3, pp. 196-206.

[67] Muncaster, P, (2012) "Ex-Alibaba GM cuffed as bribery scandal resurfaces", The Register, London.

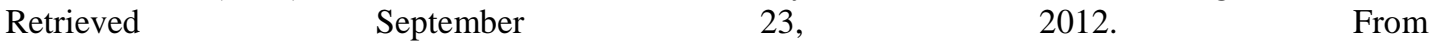
http://www.theregister.co.uk/2012/07/06/alibaba_general_manager.

[68] Sedera, D., and Dey, S, (2013) "User expertise in contemporary information systems: Conceptualization, measurement and application", Information and Management, Vol. 50, pp. 621637.

[69] Shukla, P, (2014) "The impact of organizational efforts on consumer concerns in an online context", Information and Management, Vol. 51, pp. 113-119.

[70] Soper, D. S, (2010)“Statistics calculations”, Retrieved, from https://www.daniesoper.com/statcalc/.

[71] Sun, Y., and Jeyara, A, (2013) "Information technology adoption and continuance: A longitudinal study of individuals' behavioral intentions", Information and Management, Vol. 50, pp. 457-465.

[72] Tang, J., Huang Y., and Wu, C, (2013) "Investigating the effects of business process orientation on organizational innovation performance", Information and Management 50, pp. 650-660.

[73] Timers, P, (2000) "Electronic commerce: Strategies and models for business-to-business trading", New York: John Wiley and Sons, pp31.

[74] Wu, C. S., Cheng, F. F., Yen, D. C., and Huang, Y. W, (2011) "User acceptance of wireless technology in organizations: A comparison of alternative model", Computer Standards and Interfaces, Vol. 33, No. 1, pp. 50-58. 
International Journal of Database Management Systems ( IJDMS ) Vol.9, No.3, June 2017

[75] Wallace, L. G., and Sheetz, S. D, (2014) "The adoption of software measures: A technology acceptance model (TAM) perspective", Information and Management, Vol. 51, pp. 249-259.

[76] Shao, Hong, Shuang Chen, Jie-yi Zhao, Wen-cheng Cui, and Tian-shu Yu, (2015) "Face recognition based on subset selection via metric learning on manifold," Frontiers of Information Technology \& Electronic Engineering, 16, no. 12, pp 1046-1058.

[77] Tan, Min, Zhenfang Hu, Baoyuan Wang, Jieyi Zhao, and Yueming Wang, (2016) "Robust object recognition via weakly supervised metric and template learning." Neurocomputing 181, pp 96-107.

[78] Zhou, Lingxi, William Hoskins, Jieyi Zhao, and Jijun Tang, (2015) "Ancestral reconstruction under weighted maximum matching." In Bioinformatics and Biomedicine (BIBM), 2015 IEEE International Conference on, pp. 1448-1455.

[79] Jie-Yi Zhao, Min Tang, Ruo-Feng Tong, (2012) "Connectivity-based segmentation for GPUaccelerated mesh decompression", Journal of Computer Science and Technology, Vol 27, Iss 6, pp 1110.

[80] Peng Du, Jie-Yi Zhao, Wan-Bin Pan, Yi-Gang Wang, (2015) "GPU accelerated real-time collision handling in virtual disassembly", Journal of Computer Science and Technology, Vol 30, Iss 3, pp 511-518.

[81] M. Fan, Y. Liu, Rajesh Jha, George S. Dulikravich, J. Schwartz and C.C. Koch, (2016) "On the Formation and Evolution of Cu-Ni-rich Bridges of Alnico Alloys with Thermomagnetic Treatment," IEEE Transactions on Magnetics, vol. 52, no. 8, pp. 1-10.

[82] M. Fan, Y. Liu, Rajesh Jha, George S. Dulikravich, J. Schwartz and C.C. Koch, (2016) "On the Evolution of $\mathrm{Cu}-\mathrm{Ni}^{-}$rich Bridges of Alnico Alloys with Tempering," Journal of Magnetism and Magnetic Materials, vol. 420, pp 296-302.

[83] Xie, J.; Zhai, X.; Hse, C.; Shupe, T.; Pan, H, (2015) "Polyols from Microwave Liquefied Bagasse and Its Application to Rigid Polyurethane Foam", Materials, No. 8, Iss.12, pp 8496-8509.

[84] Gao, Z.; Zhai, X.; Wang, C, (2015) "Facile transformation of superhydrophobicity to hydrophilicity by silica/poly( $\varepsilon$ caprolactone) composite film”, Applied Surface Science, No. 359, pp 209-214.

[85] Zhang, B., Pradeep, CP., Cronin, L., Liu, T., (2015) "Self-assembly of triangular polyoxometalateorganic hybrid macroions in mixed solvents", Chemical communications, No 51, Iss 41, pp 86308633.

[86] B Zhang, J Song, D Li, L Hu, CL Hill, T Liu, (2016) "Self-Assembly of Polyoxovanadate-Containing Fluorosurfactants", Langmuir, No 32, Iss 48, pp, 12856-12861.

[87] L. Gong, Y. Yang, K. Y. Chan, and R. Ramer, "RHCP pattern-reconfigurable spiral antenna biased with two DC signals," Microwave and Optical Technology Letters, vol. 56, pp. 1636-1640, 2014.

[88] L. Gong, R. Ramer, and K. Y. E. Chan, "Beam steering spiral antenna reconfigured by PIN diodes," International Journal of Microwave and Wireless Technologies, vol. FirstView, pp. 1-9, 2014.

[89] G. Liang, C. King Yuk, Y. Yi, and R. Rodica, "RF MEMS for Reconfigurable RF Front-end: Research in Australia," Advanced Materials Research, vol. Volume 901, pp. 105-110, February 2014.

[90] Yajin Zhou, Xiaoguang Wang, Yue Chen, and Zhi Wang, (2014) "Armlock: Hardware-based fault isolation for arm", Proceedings of the 21st ACM SIGSAC Conference on Computer and Communications Security (CCS 2014).

[91] G. Liang, C. King Yuk, and R. Ramer, "A beam steering single-arm rectangular spiral antenna with large azimuth space coverage," in Wireless and Microwave Technology Conference (WAMICON), 2013 IEEE 14th Annual, 2013, pp. 1-4.

[92] G. Liang, C. King Yuk, and R. Ramer, "A reconfigurable spiral antenna with wide beam coverage," in Antennas and Propagation Society International Symposium (APSURSI), 2013 IEEE, 2013, pp. 206207.

[93] Baiyu Chen, Sergio Escalera, Isabelle Guyon, Víctor Ponce-López, Nihar Shah, Marc Oliu Simón, (2016), "Overcoming calibration problems in pattern labeling with pairwise ratings: application to personality traits", Computer Vision--ECCV 2016 Workshops, pp 419-432, 2016.

[94] Víctor Ponce-López, Baiyu Chen, Marc Oliu, Ciprian Corneanu, Albert Clapés, Isabelle Guyon, Xavier Baró, Hugo Jair Escalante, Sergio Escalera, (2016), "ChaLearn LAP 2016: First Round Challenge on First Impressions-Dataset and Results”, Computer Vision--ECCV 2016 Workshops, pp 400-418, 2016.

[95] Zhengyu Yang, Manu Awasthi, Mrinmoy Ghosh, Ningfang Mi, (2016) "A Fresh Perspective on Total Cost of Ownership Models for Flash Storage", 8th IEEE International Conference on Cloud Computing Technology and Science. 
[96] Zhengyu Yang, Jianzhe Tai, Janki Bhimani, Jiayin Wang, Ningfang Mi, Bo Sheng, (2016) "GREM: Dynamic SSD Resource Allocation in Virtualized Storage Systems with Heterogeneous IO Workloads", 35th IEEE International Performance Computing and Communications Conference.

[97] Zhengyu Yang, Jiayin Wang, David Evans, Ningfang Mi, (2016) "AutoReplica: Automatic Data Replica Manager in Distributed Caching and Data Processing Systems", 1st IEEE International Workshop on Communication, Computing, and Networking in Cyber Physical Systems.

[98] Han Gao, Zhengyu Yang, Janki Bhimani, Teng Wang, Jiayin Wang, Ningfang Mi, Bo Sheng, (2017) "AutoPath: Harnessing Parallel Execution Paths for Efficient Resource Allocation in Multi-Stage Big Data Frameworks", 26th International Conference on Computer Communications and Networks.

[99] Jianzhe Tai, Deng Liu, Zhengyu Yang, Xiaoyun Zhu, Jack Lo, Ningfang Mi, (2015) "Improving Flash Resource Utilization at Minimal Management Cost in Virtualized Flash-based Storage Systems", in IEEE Transactions on Cloud Computing, vol.PP, no.99, pp.1-1.

[100]Yue Chen, Zhi Wang, David Whalley, and Long Lu, (2016) "Remix: On-demand live randomization", Proceedings of the 6th ACM Conference on Data and Application Security and Privacy, pp 50-61.

[101] Yue Chen, Mustakimur Khandaker, and Zhi Wang, (2017) "Secure in-cache execution", Proceedings of the 20th International Symposium on Research in Attacks, Intrusions and Defenses (RAID 2017).

[102]Long Cheng, Spyros Kotoulas, Tomas Ward, Georgios Theodoropoulos, (2014) "Robust and Skewresistant Parallel Joins in Shared-nothing Systems", Proceedings of the 23rd ACM International Conference on Information and Knowledge Management, pp 1399-1408.

[103] Guocai Chen, Jieyi Zhao, Trevor Cohen, Cui Tao, Jingchun Sun, Hua Xu, Elmer V. Bernstam, Andrew Lawson, Jia Zeng, Amber M. Johnson, Vijaykumar Holla, Ann M. Bailey, Humberto LaraGuerra, Beate Litzenburger, Funda Meric-Bernstam and W. Jim Zheng, (2015) "Using Ontology Fingerprints to disambiguate gene name entities in the biomedical literature", Database, Vol. 2015(1):bav034.

[104] Yue Chen, Mustakimur Khandaker, and Zhi Wang, (2017) "Pinpointing vulnerabilities", Proceedings of the 12th ACM Asia Conference on Computer and Communications Security, pp 334-345.

[105]Guocai Chen, Michael J. Cairelli, Halil Kilicoglu, Dongwook Shin, Thomas C. Rindflesch, (2014) "Augmenting Microarray Data with Literature-Based Knowledge to Enhance Gene Regulatory Network Inference”, PLoS Comput Biol, Vol. 10(6): e1003666.

[106]Xianzhi Du, Mostafa El-Khamy, Jungwon Lee, Larry S Davis, (2017) "Fused DNN: A Deep Neural Network Fusion Approach to Fast and Robust Pedestrian Detection", IEEE Winter Conference on Applications of Computer Vision (WACV), pp 953-961.

[107]Xianzhi Du, David S. Doermann, Wael Abd-Almageed, (2015) "A graphical model approach for matching partial signatures", IEEE Conference on Computer Vision and Pattern Recognition (CVPR), pp 1465-1472

[108] Guocai Chen, Jim Warren, Patricia Riddle, (2011) "Semantic Space Models for Classification of Consumer Web Pages on Metadata Attributes", Journal of Biomedical Informatics, Vol. 43(5):725735 .

[109] Guocai Chen, Jim Warren, Joanne Evans, (2009) “'Qualities' not 'Quality' - Text Analysis Methods to Classify Consumer Health Websites”, electronic Journal of Health Informatics, Vol. 4(1): e5

[110]Kewei Zhang, Lin Zhang, Yuesheng Chai, (2015) "Mass load distribution dependence of mass sensitivity of magnetoelastic sensors under different resonance modes", Sensors Vol.15, pp 2026720278

[111]Yizheng Cao, Pablo Zavattieri, Jeffrey Youngblood, Robert Moon, Jason Weiss, "The Influence of Cellulose Nanocrystal Additions on the Performance of Cement Paste", Cement and Concrete Composites, vol. 56, pp73-83, 2015.

[112]Xiaoguang Wang, Yue Chen, Zhi Wang, Yong Qi, and Yajin Zhou, (2015) "SecPod: a framework for virtualization-based security systems", Proceedings of the 2015 USENIX Annual Technical Conference (USENIX ATC 15), pp 347-360.

[113] Kewei Zhang, Lin Zhang, Liling Fu, Suiqiong Li, Huiqin Chen, and ZhongYang Chen, (2013) "Magnetostrictive resonators as sensors and actuators", Sensorsand Actuators: A. Physical, Vol 200, pp 2-10.

[114] Yizheng Cao, Pablo Zavattieri, Jeffrey Youngblood, Robert Moon, Jason Weiss, "The relationship between cellulose nanocrystal dispersion and strength", Construction and Building Materials, vol. 119, pp71-79, 2016 
[115]Kewei Zhang, Liling Fu, Lin Zhang, Zhongyang Cheng, and Tung-Shi Huang, (2014) "Magnetostrictive particle based biosensors for in-situ and real-time detection of pathogens in water", Biotechnology and Bioengineering, Vol.111, pp2229-2238.

[116] Yue Chen, Yulong Zhang, Zhi Wang, Liangzhao Xia, Chenfu Bao, and Tao Wei, (2017) "Adaptive android kernel live patching", Proceedings of the 26th USENIX Security Symposium (USENIX Security 17).

[117] Yizheng Cao, Nannan Tian, David Bahr, Pablo D. Zavattieri, Jeffrey Youngblood, Robert J. Moon, Jason Weiss, (2016) "The influence of cellulose nanocrystals on the microstructure of cement paste", Cement and Concrete Composites, Vol. 74, pp164-173.

[118] Yizheng Cao, W. Jason Weiss, Jeffrey Youngblood, Robert Moon \& Pablo Zavattieri, (2015) "Performance-Enhanced Cementitious Materials by Cellulose Nanocrystal Additions", Cement and Concrete Composites, Vol. 56, pp 73-83.

[119]Jun Wang, Wei Zhang, Rui Cao, Xiaoyu You, Hong Lai, (2016) “Analysis of Nitrogen Dioxide in Environment”, Advances in Bioscience and Biotechnology, Vol 7, p278-288.

[120]Shan Xi Tian, Xiang Sun, Rui Cao, Jinlong Yang, (2009) "Thermal Stabilities of the Microhydrated Zwitterionic Glycine: A Kinetics and Dynamics Study”, J. Phys. Chem. A, Vol 113, p480-483.

\section{AUTHOR S}

Dr. Ren now is the Adjunct Faculty in San Jose City College, teaching CIS60 System Analysis and Design, with Bachelor of Management from Anhui University China, Master of Business Administration from School of Business and Law Victoria University Melbourne, Australia, and Doctor of Business Administration from Business and Information Technology Management School in Northwestern Polytechnic University, Fremont California USA.She is Hi-tech enthusiast and self-upgraded to latest software skills, SAP, SAS, SPSS and Amos in quantitative research method, self-learning on HTML, C++, Java, Python, and Swift code, also she has research interests on visualized data analysis by $\mathrm{R}$, and robotics EV3 programming etc.

Liang huang is an associate Professor, Electronics College of Zhejiang Gongshang University. He got phd from Zhejiang University china, and finished his postdoc at Polytechnic of Turin, Italy, and Hanyang University, Seoul, Korea. His research is mainly focus on Research on: Intelligent Control; Electrical Robotics. 